Original Research

\title{
The Relationship Between Family Support and Quality of Life Improvement of Patients with Diabetes Mellitus in Semarang
}

\author{
Iskim Luthfa, Moch Aspihan, and Muhammad Rifqi Lathif
}

Sultan Agung Islamic University, Semarang, Indonesia

\begin{abstract}
Introduction: Diabetes mellitus (DM) is known as the silent killer, where sufferers often do not realize its signs and symptoms and are frequently diagnosed during another health complication. To maintain quality of life, the family is required to provide support, therefore, this study aims to determine the relationship between family and the patient through observational analytic research.
\end{abstract}

Methods: 120 people with DM make up the research sample using an accidental sampling technique, and data analysis was carried out using the Spearman rank test. The results found that 62 respondents $(51.7 \%)$ agreed to their families providing good support, and 102 (85\%) were satisfied with their quality of life.

Results: The Spearman test resulted in a $P$ value of 0,000 and $R$ of 0.334 . This means the higher the support provided by the family, the greater the increase in quality of life.

Conclusion: The suggestions proposed from this study is for health workers to advocate and encourage family in the planning management of DM sufferers in order to improve their quality of life.

\section{ARTICLE HISTORY}

Received: Dec 26, 2019

Accepted: Dec 31, 2019

\section{KEYWORDS}

quality of life; diabetes mellitus; good support

\section{CONTACT}

Iskim Luthfa

$\checkmark$ iskimluthfa@unissula.ac.id

$\supseteqq$ Sultan Agung Islamic University, Semarang, Indonesia

Cite this as: Luthfa, I., Aspihan, M., \& Lathif, M.R. (2019). The Relationship Between Family Support and Quality of Life Improvement of Patients with Diabetes Mellitus in Semarang. Jurnal Ners, 14(3si), 327-330. doi:http://dx.doi.org/10.20473/in.v14i3(si).17175

\section{INTRODUCTION}

Diabetes Mellitus (DM) is a disease where the incidence rate increases every year (IDF, 2015). Up to 2030, Indonesia is predicted to rank fourth for the highest number of DM patients in the world (Wild, Roglic, Green, Sicree, \& King, 2004). DM sufferers are predicted to decline in life expectancy, however the benchmark is still uncertain as it is a prolonged disease. The results of a study conducted by Loukine, Waters, Choi, \& Ellison (2012) found that a person aged 55 years and suffering from DM will lose 6 years off of their life expectancy. On average, complications are experienced 11 years are diagnosis (Ludirdja, Kencana, Kurniawan, Adyana, \& Aryana, 2010), including one, or a combination of, retinopathy, neuropathy, nephropathy, and heart disease (Restada, 2016). The American Heart Association (2018) states that $68 \%$ of DM patients aged 65 die from heart disease and stroke, and not as a result of their diabetes.
Isa \& Baiyewu (2006) reported that DM has a negative impact on quality of life. Of the $251 \mathrm{DM}$ patients, $52(20.7 \%)$ agreed they had a good quality of life, 164 respondents (65.4\%) had fairly good, and 35 respondents (31.9\%) had low. According to Taylor (2006), quality of life is related to a person's ability to adapt to a disease, as indicated by their physical, social, psychological, and occupational functions. Some factors include the ability to perform self-care (Chaidir, Wahyuni, \& Furkhani, 2017), nutritional status (Setiyorini \& Wulandari, 2017), ability to do physical activities (Timisela, Ratag, \& Kalesaran, 2017), and the avoidance of psychological conditions such as stress (Zainuddin, Utomo, \& Herlina, 2015).

In addition to these factors, family support is important in improving quality of life (Nuraisyah, Kusnanto, \& Rahayujati, 2017), where assistance is provided by families to other members who suffer illnesses to maintain and improve their health status (Luthfa, 2016). According to (Hensarling, 2009), there are four dimensions available to help families, which are emotional, appreciative, instrumental and 
informational. The purpose of this study was to determine the relationship between family support and the quality of life for DM patients in the city of Semarang.

\section{MATERIALS AND METHODS}

This was an observational analytic study with a cross sectional approach. 225 DM patients treated at the Semarang Bangetayu Health Center were respondents. Samples were taken using the accidental sampling method (Sastroasmoro, 2014), and 120 respondents were obtained. The sample criteria in this study includes DM patients who live with their families and were having treatment at the Semarang Public Health Center.

The research instrument to measure family support included the Hensarling Diabetes Family Support Scale (HDFSS). Meanwhile, the instrument to measure the quality of life for DM patients was Diabetic Quality of Life (DQOL). The processed data was then analyzed in both univariate and bivariate. The univariate analysis uses the frequency distribution, whereas the bivariate utilizes the Spearman rank test.

Table 1. Frequency distribution of respondent characteristics.

\begin{tabular}{lll}
\hline Variable & (f) & $(\%)$ \\
\hline Sex & & 44,2 \\
Male & 53 & 55,2 \\
Female & 67 & \\
\hline Age & & \\
$26-45$ & 13 & 10,8 \\
$46-80$ & 107 & 89,2 \\
\hline Education & & \\
Elementary school & 103 & 85,8 \\
Junior high school & 16 & 13,4 \\
Senior high school & 1 & 0,8 \\
\hline Family support: & & \\
Good & 62 & 51,7 \\
Very good & 58 & 48,3 \\
\hline Quality of life & & \\
Satisfied & 102 & 85 \\
Not satisfied & 18 & 15 \\
\hline
\end{tabular}

Table 2. Relationship between family support and the quality of life of patients with DM.

\begin{tabular}{llll}
\hline Variable & $\mathrm{N}$ & P value & $\mathrm{r}$ \\
\hline Family & 120 & 0.000 & 0.334 \\
support & & & \\
$\begin{array}{l}\text { Quality of } \\
\text { life }\end{array}$ & & & \\
\hline
\end{tabular}

\section{RESULTS}

\section{Respondent characteristics}

Table 1 shows that the majority of respondents were female, at 67 respondents $(55.2 \%)$, most of them were aged 46-80 years at 107 respondents (89.2\%), most of them had a low education level, 103 respondents $(85.8 \%)$, most of them get support from the family with a good category, 62 respondents
(51.7\%), and most were satisfied with the quality of life, 102 respondents (85\%).

\section{Relationship between family support and the quality of life}

Table 2 results of the Spearman rank test shows a pvalue of $0,000(\mathrm{p}$-value $<0.05)$ and a Spearman rank correlation value of 0.334 , meaning that there is a relationship between family support and quality of life. The higher the support given by the family, the better quality of life for people with DM.

\section{DISCUSSION}

The majority of respondents were female, as they are more at risk of gestational diabetes due to pregnancy. They also experience an increase in BMI that leads to obesity after pregnancy. These conditions cause DM to be more common among women than men. Table 1 also shows that 107 respondents $(89.2 \%)$ were aged 46-80, with 54 being the classifier for early stages of being elderly. Someone of old age will experience a decrease in producing the insulin hormone in the pancreas, thus increasing the risk of DM.

Furthermore, Table 1 also indicates that 103 respondents $(85.8 \%)$ had a low level of education, which usually produces an increase in cognitive, affective and psychomotor abilities (Notoatmodjo, 2003). Highly educated people tend to have more knowledge and understanding in maintaining their health, while people those who are limited in their education have minimal access to that information, making it difficult to recognize the signs of DM (Fahra, Widayati, \& Sutawardana, 2017).

It is also shown that 62 respondents (51.7\%) received good support from their family, and 102 $(85 \%)$ felt satisfied with their quality of life. Family support is a process of giving assistance to other members who suffer health issues that impact physical and psychological comfort (Sepulveda, Poihos, Ribeiro, Freitas, \& Carvalho, 2015), this is recommended to improve the quality of life of people with DM. The results of the Spearman rank test in Table 2 showed that the higher the support provided by the family, the greater the increase in quality of life.

The results of this study are consistent with the research conducted by Fatusin, Agboola, Shabi, Bello, \& Elegbede (2016). Family has a positive correlation with the quality of life for people with DM, with an improvement through emotional, appreciative, instrumental and informational support (Nuraisyah et al., 2017).

The first dimension is emotional support: Friedman, Bowden, \& Jones (2010) state that it is included in the affective function of the family, as families provide support for psychological issues experienced by DM sufferers, such as stress and anxiety. Giving emotional support will encourage people with type 2 diabetes to control their emotions and be aware of complications that will arise in the future. The support provided by the family will have a positive impact on the growth and development of 
family members (Friedman et al., 2010), and can reduce despair, inferiority and limitations due to physical disabilities experienced (Felpina, Wiyono, \& Maryah, 2016).

The second dimension is appreciation. This is feedback given by the family based on the condition of the patient. Appraisal support is considered to increase enthusiasm, motivation, and self-esteem as sufferers will still feel useful and meaningful to their family (Ferawati, Hasibuan \& Wicaksono, A., 2014).

The third dimension is instrumental support, where real and direct assistance is provided in the form of personnel assistance, facilities and funds, including free time to serve and listen to complaints (Bomar, 2004; Sandra J.Peterson, 2017).

The last dimension is information support. It is very important, yet sometimes difficult, for families to provide support because they do not have enough information in managing diabetes (Luthfa, 2016). They should look at diet, potential physical activity, conditions or symptoms of complications of DM, and how to treat it.

The four dimensions of family support above should be given as a whole by the family to help sufferers in the management of DM treatment. Correct and regular management, as well as support from the family, can make patients feel unencumbered and uplifted in the process of treatment and activities. This will improve the quality of life for people with DM physically, psychologically and socially (Nuraisyah et al., 2017).

\section{CONCLUSION}

Most DM patients have support from families in good categories and are left satisfied with their quality of life. Family support has a positive correlation to quality of life, the more support provided by the family, the more satisfied they are. Health workers have to encourage families in planning management of DM patients in order to improve their quality of life.

\section{REFERENCES}

ADA. (2018). American heart association and american diabetes association launch landmark health initiative-Know diabetes by Heart.

Bomar, P. . (2004). Promoting health in families: Applying family research and theory to nursing practice. Saunders: Lippincot.

Chaidir, R., Wahyuni, A. S., \& Furkhani, D. W. (2017). Hubungan self care dengan kualitas hidup pasien diabetes melitus. Endurance, 2(June), 132-144.

Fahra, R. U., Widayati, N., \& Sutawardana, J. H. (2017). Hubungan peran perawat sebagai sebagai edukator dengan perawatan diri pasien diabetes mellitus tipe 2 di Poli Penyakit Dalam Rumah Sakit Bina Sehat Jember. Nurseline Journal, 2(1), 61-72.

Fatusin, A. ., Agboola, S. ., Shabi, 0. ., Bello, I. ., \& Elegbede, O. . (2016). Relationship between family support and quality of life of type-2 diabetes mellitus patients attending family medicine clinic, federal medical centre, IdoEkiti. Nigerian Journal of Family Practice, 7(2).

Federation, I. D. (2015). Diabetes Atlas.

Felpina, D. ., Wiyono, J., \& Maryah, V. (2016). Hubungan dukungan keluarga dengan kemandirian lansia dalam pemenuhan ADL di Kelurahan Tlogomas Kota Malang. Nursing News, 1(2), 101-114.

Friedman, Bowden, \& Jones. (2010). Buku ajar keperawatan keluarga: riset, teori dan praktik. Jakarta: EGC.

Hensarling, J. (2009). Development and psychometric testing of hensarling's diabetes family support scale.

Isa, B. ., \& Baiyewu, O. (2006). Quality Of Life patient with diabetus melitus in a Nigerian Teaching hospital. Hongkong Jurnal Psychiatry, 16, 27-33.

Loukine, L., Waters, C., Choi, B. C. K., \& Ellison, J. (2012). Impact of diabetes mellitus on life expectancy and health-adjusted life expectancy in Canada. Jurnal Boimed Central, 10(1), 1-10. https://doi.org/10.1186/1478-7954-10-7

Ludirdja, J. ., Kencana, L., Kurniawan, K., Adyana, M. ., \& Aryana, I. . (2010). Rerata durasi penderita diabetes melitus terkena nefropati diabetik sejak terdiagnosis diabetes melitus pada pasien di poliklinik geriatri rsup sanglah. Jurnal IPTEKMA, 2(1), 1-4.

Luthfa, I. (2016). Family support pada penderita diabetes mellitus tipe 2 di Puskesmas Bangetayu Semarang, Analisis Rasch Model. Jurnal Keperawatan Dan Pemikiran Ilmiah Nurscope, 2(2), 1-12.

Notoatmodjo, S. (2003). Pendidikan dan perilaku kesehatan. Jakarta: Rineka Cipta.

Nuraisyah, F., Kusnanto, H., \& Rahayujati, T. (2017). Dukungan keluarga dan kualitas hidup pasien diabetes mellitus. Journal of Community Medicine and Public Health, 33(1), 55-65.

Restada, E. . (2016). Hubungan lama menderita dan komplikasi diabetes melitus dengan kualitas hidup pada penderita diabetes melitus di wilayah Puskesmas Gatak Sukoharjo.

Sandra J.Peterson, T. S. B. (2017). Middle Range Theories; Application to Nursing Research and Practice. In Wolters Kluwer (Fourth Edi). Philadelphia: Wolters Kluwer.

Sastroasmoro, S. (2014). DAsar-dasar metodologi penelitian klinis (5th ed.). Jakarta: Sagung Seto.

Sepulveda, E., Poihos, R., Ribeiro, J. P., Freitas, P., \& Carvalho, D. (2015). Health-related quality of life in type 1 and type 2 diabetic patients in a Portuguese central public hospital. Diabetes, Metabolic Syndrome and Obesity: TArget and Therapy, 8(Maret), 219-226.

Setiyorini, E., \& Wulandari, N. A. (2017). Hubungan status nutrisi dengan kualitas hidup pada lansia penderita diabetes mellitus tipe 2 yang berobat di Poli Penyakit Dalam RSD Mardi Waluyo Blitar. Jurnal Ners Dan Kebidanan, 4(2), 125- 
I. LUTHFA, ET AL.

133. https://doi.org/10.26699/jnk.v4i

Taylor, S. . (2006). Health psychology. Sixth Edition. Singapore: Mc Grow Hill Book Company.

Timisela, J. ., Ratag, B. ., \& Kalesaran, A. F. . (2017). Hubungan aktivitas fisik dengan kualitas hidup pasien dm tipe ii di rsu pancaran kasih. 1-6.

Wild, S., Roglic, G., Green, A., Sicree, R., \& King, H. (2004). Global prevalence of diabetes: estimates for the year 2000 and projections for 2030. Jurnal Diabetes Care, 27(5), 1047-1053.

Zainuddin, M., Utomo, W., \& Herlina. (2015). Hubungan stres dengan kualitas hidup penderita diabetes mellitus tipe 2. JOM, 2(1), 890-898. 